\title{
Pengembangan Modul Pembelajaran Instalasi Tenaga Listrik Di SMK Muhammadiyah 1 Padang
}

\author{
Alimah Zikra Tampal ${ }^{1 *}$, Fivia Eliza ${ }^{1}$ \\ ${ }^{1}$ Jurusan Teknik Elektro, Fakultas Teknik, Universitas Negeri Padang \\ *e-mail: alimahzikratampa197@gmail.com \\ (Diajukan: 04 Desember 2020, direvisi:18 Desember 2020, disetujui: 05 Januari 2021)
}

\begin{abstract}
Abstrak
Penelitian ini bertujuan untuk menghasilkan modul pembelajaran Instalasi Tenaga Listrik yang valid dan praktis di SMK Muhammadiyah 1 Padang. Penelitian ini menggunakan metode penelitian pengembangan (Research and Development) dengan model 4D. Subjek penelitian ini adalah siswa kelas XI TITL di SMK Muhammadiyah 1 Padang pada semester satu tahun ajaran 2020/2021. Berdasarkan hasil penelitian diperoleh validitas media $90.0 \%$ dengan kategori valid. Validitas materi rata-rata sebesar $87.50 \%$ dengan kategori valid. Uji praktikalitas dengan responden guru rata-rata sebesar $86,55 \%$ dengan kategori sangat praktis dan responden siswa kelas XI TITL SMK Muhammadiyah 1 Padang dengan nilai rata-rata $84,52 \%$ menyatakan modul pembelajaran instalasi tenaga listrik dikategori sangat praktis. Disimpulkan bahwa modul pembelajaran Instalasi Tenaga Listrik adalah valid dan praktis dapat digunakan dalam proses belajar mengajar di sekolah.
\end{abstract}

Kata Kunci: modul instalasi tenaga listrik, valid, praktis, research \& development.

\begin{abstract}
This study aims to produce a valid and practical Electrical Power Installation learning module at SMK Muhammadiyah 1 Padang. This study uses a research and development method with a 4D model. The subjects of this study were students of class XI TITL at SMK Muhammadiyah 1 Padang in the first semester of the 2020/2021 school year. Based on the research results, the validity of the media was $90.0 \%$ with the valid category. The validity of the material on average is $87.50 \%$ with the valid category. Practicality test with teacher respondents an average of $86.55 \%$ with a very practical category and student respondents of class XI TITL SMK Muhammadiyah 1 Padang with an average value of $84.52 \%$ stated that the electric power installation learning module was in the very practical category. It is concluded that the Electric Power Installation learning module is valid and practical and can be used in the teaching and learning process in schools.
\end{abstract}

Keywords: electric power installation learning module, valid, practical, research \& development. 


\section{PENDAHULUAN}

Pendidikan merupakan sebuah sarana yang efektif dalam mendukung perkembangan serta peningkatan Sumber Daya Manusia (SDM) kearah yang lebih baik. Kemajuan suatu bangsa bergantung kepada SDM yang berkualitas, hal itu sangat ditentukan oleh pendidikan [1]. Pembelajaran merupakan hal yang penting, artinya tercapainya tujuan pendidikan tergantung pada proses belajar yang dijalani oleh peserta didik. Proses pembelajaran adalah upaya bersama antara guru dan siswa untuk berbagi dan mengolah informasi agar bermanfaat bagi siswa yang ditandai dengan perubahan tingkah laku ke arah yang lebih baik. Adapun indikator keberhasilan proses belajar salah satunya adalah hasil belajar siswa [2].

Salah satu faktor penting dalam mempengaruhi hasil belajar siswa yaitu faktor sekolah dimana didalamnya terdapat guru sebagai pendidik,siswa sebagai peserta didik dan sarana prasarana sebagai alat penunjang pendidikan [3]. Sarana pendidikanmerupakan mencakup semua peralatan dan perlengkapan yangsecara langsung digunakan dan menunjang dalam suatu prosespendidikan harus sesuai dengan proses pembelajaran. Sedangkan prasarana pendidikan adalah fasilitas yang secara tidak langsung menunjang jalannya proses pendidikan [4].

Sebagai salah satu lembaga pendidikan,kondisi prasarana sekolah di SMK Muhammadiyah 1 Padang sudah tergolong lengkap, mulai dari ruang kelas,workshop dan perpustakaan yang memadai. Namun untuk sarana pembelajaran yang tersedia di sekolah masih belum lengkap. Hal ini dapat terlihat pada tidak tersedianya sumber belajar bagi siswa,yang salah satunya ada pada pembelajaran Instalasi Tenaga Listrik (ITL). Hal ini menyebabkan siswa kesulitan untuk belajar secara mandiri sebagaimana tuntutan Kurikulum 2013. Selain tuntutan kurikulum 2013, proses pembelajaran daring sebagai dampak dari pandemi covid-19 juga menuntut siswa untuk dapat belajar secara mandiri.

Berdasarkan pendekatan pembelajaran daring,belajar mandiri merupakan pokok bahasan yang perlu perhatian khusus. Proses belajar mandiri membutuhkan media pembelajaran yang cocok untuk mencapai tujuan pembelajaran. Sekarang ini, media yang diterapkan masih berupa handout atau modul yang belum sempurna. Handout hanya berisikan materi pembelajaran dan 5 butir soal evaluasi. Pemberian handout belum memberikan hasil yang maksimal pada pembelajaran yang ditandai dengan banyaknya siswa yang gagal dalam memenuhi SKM yang di tetapkan.

Selain itu, berdasarkan observasi pada Januari hingga Maret 2020 di kelas XI TITL, dalam pelaksanaan proses pembelajaran secara garis besar masih menggunakan metode ceramah dan penugasan. Pada saat menyampaikan materi guru yang berperan aktif, sehingga menghambat keaktifan siswa. Guru menyampaikan materi pembelajaran sesuai handout, sementara siswa diharuskan mencatat semua materi handout tersebut. Kondisi ini menyebabkan banyaknya waktu terbuang hanya untuk mencatat materi tanpa melakukan pendalaman materi.

Berdasarkan paparan di atas diperlukan solusi untuk mengatasi permasalahan tersebut. Penggunaan bahan ajar berupa modul bagi peserta didik dapat dijadikan alternatif guru untuk meningkatkan penguasaan materi dan hasil belajar peserta didik [5]. Modul yang baik harus valid, praktis dan efektif. Modul yang valid yaitu modul 
yang telah di periksa oleh pakar atau ahli sehingga dapat diketahui tingkat kelayakannnya. Adapun modul yang praktis adalah modul yang mudah penggunaanya,mudah pemeriksaannya dan dilengkapi dengan petunjuk yang jelas. Sedangkan keefektifan modul yaitu, modul yang digunakan dapat meningkatkan hasil belajar siswa [6].

Modul pembelajaran merupakan suatu paket program yang disusun dalam bentuk satuan tertentu dan desain sedemikian rupa guna kepentingan belajar siswa [7]. Modul memungkinkan siswa memiliki kecepatan tinggi dalam belajar akan lebih cepat menyelesaikan satu atau lebih kompetensi dasar dibandingkan oleh siswa lainnya. Dan mampu mengevaluasi diri, sehingga dapat mengoptimalkan hasil belajar [8]. Unsurunsur yang ada dalam modul yaitu, rumusan tujuan instruksional yang eksplisit dan spesifik, petunjuk guru, lembar kegiatan siswa, lembar kerja siswa, kunci lembar kerja, lembar evaluasi, kunci lembar evaluasi [9]. Modul pembelajaran juga bermanfaat bagi guru, yaitu guru tidak perlu lagi mencatatkan semua materi yang disampaikannya untuk peserta didik, sehingga waktu yang terbuang untuk mencatat sebelumnya bisa dimaksimalkan dengan melakukan pendalaman materi atau dengan melakuakan diskusi kelompok dan pembahasan soal latihan. Modul pembelajaran yang diterapkan dapat mempermudah dalam penyerapan informasi, sehingga peserta didik bisa lebih aktif ketika pembelajaran sedang berlangsung [10].

Kerangka modul pembelajaran yang dikembangkan terdiri dari deskripsi judul, petunjuk penggunaan modul untuk siswa, kegiatan pembelajaran, tujuan pembelajaran, materi pembelajaran, kesimpulan, latihan soal, tes formatif, dan kunci jawaban soal. Tugas latihan soal tediri dari soal pertanyaan yang bertujuan untuk mengukur tingkat pemahaman siswa dalam proses pembelajaran yang diberikan oleh guru [11]. Berdasarkan uraian diatas maka disusun suatu media pembelajaran yang berbentuk modul yang dapat memudahkan siswa dalam belajar secara mandiri.

\section{METODE}

Metode penelitian yang digunakan adalah metode pengembangan (Research and Development atau R\&D) dengan model Define, Design, Develop and Disseminate (4D). Model merupakan seperangkat prosedur yang sistematis pada suatu konsep yang akan menunjukkan penggambarannya seperti keadaan yang sebenarnya. Jenis metode penelitian pengembangan ini ialah penelitian pengembangan yang digunakan untuk menghasilkan sebuah product tertentu dan menguji kevaliditan dan kepraktikalitasnya. Penelitian pengembangan yang dilakukan pada mengembangkan modul pada mata pelajaran Instalasi Tenaga Listrik kelas XI TITL SMK Muhammadiyah 1 Padang dengan responden 18 orang siswa dan 2 orang guru mata pelajaran Instalasi Tenaga Listrik pada semester satu tahun ajaran 2020/2021.

\section{Validitas Produk}

Proses validitas ini dilakukan agar menghasilkan modul yang valid. Modul yang dihasilkan pada tahap ini akan divalidasi oleh tiga validator yaitu dua orang validator dari dosen jurusan Teknik Elektro Fakultas Teknik Universitas Negeri Padang dan satu orang guru mata pelajaran ITL Kelas XI TITL di SMK Muhammadiyah 1 Padang. 
Validator mengisi instrument penelitian berupa angket validasi yang memberi masukan dan saran terhadap modul yang telah dikembangkan. Untuk mementukan validitas produk yang duhasilkan digunakan perhitungan skala Likert [12].

Tabel 1. Indikator Skala Likert

\begin{tabular}{ccc}
\hline No & Indikator & Skor \\
\hline 1 & Sangat Setuju & 5 \\
2 & Setuju & 4 \\
3 & Netral & 3 \\
4 & Tidak Setuju & 2 \\
5 & Sangat Tidak Setuju & 1 \\
\hline
\end{tabular}

Setelah diperoleh hasil validitas, kemudian dapat diketahui nilai kevalidan dengan kategori, seperti tabel 2.

Tabel 2. Kategori Kevalidan

\begin{tabular}{ccc}
\hline No & Tingkat Pencapaian & Kategori \\
\hline 1 & $81-100$ & Sangat Valid \\
2 & $61-80$ & Valid \\
3 & $41-60$ & Cukup Valid \\
4 & $21-40$ & Kurang Valid \\
$\underline{5}$ & $\underline{0-20}$ & $\underline{\text { Tidak Valid }}$
\end{tabular}

\section{Praktikalitas Produk}

Uji Praktikalitas berfungsi untuk mengetahui tingkat kemudahan dan kepraktisan dalam penggunaan modul pembelajaran pada mata pelajaran Instalasi Tenaga Listrik. Uji praktikalitas ini hanya dilakukan pada satu kompetensi dasar yaitu KD 3.4 SOP pada pemasangan instalasi penerangan,panel dan petir. Tingkat kepraktisan modul pembelajaran dilihat dari penggunaannya oleh guru dan siswa ketika melaksanakan pembelajaran dengan menggunakan modul yang telah di revisi berdasarkan penilaian validator. Data hasil dari kepraktisan modul tersebut kemudian di analisis dengan menggunakan persamaan 1 .

$$
\text { Nilai praktikalitas }=\frac{\text { Jumlah skor yang diperoleh }}{\text { Jumlah skor maksimum }} \times 100 \%
$$

Dari hasil pengolahan nilai praktikalitas kemudian dibandingkan dengan tabel 3 dibawah ini untuk melihat tingkat pencapaian produk.

Tabel 3. Kategori Kepraktisan

\begin{tabular}{ccc}
\hline No & Pencapaian & Kategori \\
\hline 1 & $81-100$ & Sangat Praktis \\
2 & $61-80$ & Praktis \\
3 & $41-60$ & Cukup Praktis \\
4 & $21-40$ & Kurang Praktis \\
5 & $0-20$ & Tidak Praktis \\
\hline
\end{tabular}

\section{HASIL DAN PEMBAHASAN}

Modul pembelajaran dikembangkan menggunakan model pengembangan 4-D. Dalam tahap pegembangan 4-D ada empat tahapan yaitu tahap I Pendefenisian (define), 
tahap II Perancangan, (design), Tahap III Pengembangan (develop), dan tahap IV Penyebaran (Dissiminate).

Tahap Pendefenisian (define) dilakukan agar dapat mengetahui permasalahan utama yang terjadi di lapangan. Sehingga dilakukan analisis kebutuhan modul Instalasi Tenaga Listrik yang akan dikembangkan. Diantaranya analisis silabus, analisis materi, dan pengumpulan materi untuk perancangan modul. Hasil dari tahap pendefenisian (define) akan digunakan pada tahap perancangan (design) yang tediri dari merancang sketsa modul dan menyusun program terperinci yang meliputi semua komponen dan konten pada modul. Tahap pengembangan (development) adalah tahap yang dimana modul yang dikembangkan harus memenuhi kriteria valid dan praktis. Setelah melakukan pengembangan maka tahap terakhir adalah tahap penyebaran (dissiminate). Modul pembelajaran ini disebarkan pada satu orang guru mata pelajaran Instalasi Tenaga Listrik dan siswa kelas XI TITL dalam bentuk softcopy melalui link: https://classroom.google.com/w/MTE4NDA2NjU2Nzk1/t/all.

Uji Validitas modul oleh 3 validator yang terdiri dari 1 dosen ahli media dan 1 dosen ahli materi yang masing-masing dari Teknik Elektro FT-UNP, lalu 1 guru sebagai ahli materi di SMK Muhammadiyah 1 padang. Berdasarkan hasil validasi, validator memberikan perolehan skor dengan rata-rata sebesar $88 \%$ dengan kategori sangat valid yang artinya modul pembelajaran telah memenuhi syarat.

Uji praktikalitas pada satu kompetensi dasar yaitu KD 3.4 SOP Pada Pemasangan Instalasi Perumahan ,Instalasi Panel Dan Instalasi Petir dilakukan dengan memberikan angket kepada guru dan siswa sebagai pengguna modul. Responden dalam uji praktikalitas sebanyak 18 orang siswa kelas XI TITL dan 2 guru mata pelajaran Instalasi Tenaga Listrik di SMK Muhammadiyah 1 Padang. Adapun tujuan dari uji praktikalitas adalah untuk mengetahui respon siswa dan guru terhadap kemudahan penggunaan modul yang telah dikembangkan. Berdasarkan rekapitulasi kepraktisan guru mata pelajaran diperoleh hasil sebesar $86,55 \%$ dengan kategori sangat praktis. Uji praktikalitas pada siswa sebagai pengguna modul diperoleh hasil 84,52\% dengan kategori sangat praktis.

\section{KESIMPULAN}

Berdasarkan hasil penelitian dan pembahasan diatas, maka dapat disimpulkan dari pengembangan modul pembelajaran Instalasi Tenaga Listrik sebagai media pembelajaran yaitu sebagai berikut: (1) Modul pembelajaran Instalasi Tenaga Listrik pada semester ganjil untuk kelas XI TITL SMK Muhammadiyah 1 Padang sudah dinyatakan valid berdasarkan uji validitas modul pembelajaran dengan rata-rata $88 \%$,(2) Modul Pembelajaran Instalasi Tenaga Listrik pada semester ganjil untuk kelas XI TITL SMK Muhammadiyah 1 Padang sudah dinyatakan sangat praktis. Berdasarkan uji praktikalitas oleh dua orang guru mata pelajaran Instalasi Tenaga Listrik sebesar 86,55\% dengan kategori sangat praktis, sedangkan uji praktikalitas dilakukan oleh 18 orang siswa diperoleh hasil dengan perolehan rata-rata 84,52 \% dengan kategori sangat praktis. 


\section{REFERENSI}

[1] T.D.Sari, Pengembangan Modul Pembelajaran Berbasis Proyek Pada Mata Pelajaran Instalasi Penerangan Listrik Untuk Mengetahui Peningkatan Hasil Belajar Siswa Kelas Xi Tiptl Smk Negeri 7 Surabaya. Jurnal Pendidikan Teknik Elektro. Vol 04 No 02. 621-627,2015.

[2] O.Hamalik,Proses Belajar Mengajar. Jakarta: Bumi Aksara, 2004.

[3] Slameto,Belajar Dan Faktor - Faktor Yang Mempengaruhi. Jakarta: Rineka Cipta, 2010.

[4] Yermon and F.Eliza,Pengembangan Modul Pembelajaran Dasar Listrik Dan Elektronika Untuk Kelas X TITL Di SMK Negeri 1 Padang. JTEV.Vol 06.No 02,302-203,2020

[5] D. Mahadiraja and Syamsuarnis,Pengembangan Modul Pembelajaran Berbasis Daring pada Mata Pelajaran Instalasi Penerangan Listrik Kelas XI Teknik Instalasi Tenaga Listrik T.P 2019/2020 di SMK Negeri 1 Pariaman, JTEV (Jurnal Tek. Elektro Dan Vokasional), Vol.06.No.01,2020.

[6] H.G.Syafli, Administrasi Sarana Dan Prasarana.Padang, 2020.

[7] M.Patkur And T.W.Wibowo, Pengembangan Modul Pembelajaran Autocad Untuk Meningkatkan Efektivitas Pembelajaran Siswa Kelas X TPM Di SMKN 1 Sidoarjo. JPTM. Vol 01 No.03,86-96,2013.

[8] P.Prastowo,Panduan Kreatif Membuat Bahan Ajar Inovatif. Yogyakarta: Diva Press, 2011.

[9] S. Suryosubroto, Sistem Pengajaran Dengan Modul. Yogyakarta: PT Bina Aksara, 1983.

[10] Trianto,Mendesain Model Pembelajaran Inovetif-Progresif Konsep, Landasan dan Implementasinya pada KTSP, Jakarta: Kencana., 2012.

[11]A.Alimin And H.Effendi, Pengembangan Modul Pembelajaran Berbasis Daring Pada Mata Diklat Intalasi Penerangan Listrik Kelas Xi Di Sekolah Menegah Kejuruan. Journal Of Multidisciplinary Research And Development. Vol 2. Issue 4, 133-138,2020.

[12]Riduwan, Skala Pengukuran Variabel-Variabel Penelitian. Bandung: Alfabeta, 2010. 
Halaman ini sengaja dikosongkan 